\title{
Identifying Potential Markets for African Leafy Vegetables: Case Study of Farming Households in Limpopo Province, South Africa
}

\author{
Sandile Alexandra Mahlangu, ${ }^{1}$ Abenet Belete, ${ }^{2}$ Jan. J Hlongwane, ${ }^{2}$ Usapfa Luvhengo (iD, ${ }^{3}$ \\ and Ndumiso Mazibuko ${ }^{4}$ \\ ${ }^{1}$ Agricultural Research Council-Central Office, Economic Analysis Division, PTA-RSA Pretoria, South Africa \\ ${ }^{2}$ University of Limpopo, Department of Agricultural Economics and Animal Production, Polokwane, South Africa \\ ${ }^{3}$ Agricultural Economics and Extension, Faculty of Agriculture, Science and Technology, North West University, Potchefstroom, \\ South Africa \\ ${ }^{4}$ National Agricultural Marketing Council, Statutory Measures Division, Pretoria, South Africa \\ Correspondence should be addressed to Usapfa Luvhengo; luvhengousapfa@gmail.com
}

Received 19 June 2020; Revised 17 August 2020; Accepted 20 October 2020; Published 9 December 2020

Academic Editor: Mehdi Rahimi

Copyright (C) 2020 Sandile Alexandra Mahlangu et al. This is an open access article distributed under the Creative Commons Attribution License, which permits unrestricted use, distribution, and reproduction in any medium, provided the original work is properly cited.

\begin{abstract}
Indigenous crops, through their high nutritional value and hardy attributes, offer potential trade opportunities for rural farmers. There is a niche market that can be explored for these indigenous crops particularly with the growing demand for high nutritional value food in the country. These crops are mostly produced by rural households or gathered from the wild by rural farmers. Thus, the purpose of this study was to identify potential markets for African leafy vegetables (ALVs) by farmers in Limpopo Province. Sixty households producing ALVs were selected with the composition of 54 women and six men, with this selection done using a purposive sampling procedure. Of the total production, $50-60 \%$ of the produce was sold in the informal market. It was evident that local rural markets constituted a greater portion of the total market at $73 \%$ and $20 \%$ allocated to hawkers in town. As a result, urban and periurban consumers present potential buyers since these areas are populated with the middle-class population which is susceptible to changing consumption trends. Because of this potential, supermarkets and township hawkers are proposed as the potential channel for ALVs targeting the identified population. Thus, it is suggested that, in order to create a synergy between economic improvement of rural farmers and trending consumer demands, the Department of Agriculture in Limpopo Province creates a conducive environment through which ALV farmers can be connected with supermarkets and township marketers.
\end{abstract}

\section{Introduction}

Markets are important for economic growth and sustainable development of a given country, but emphasis has been placed on increasing agricultural production for rural development in policies of agrarian countries. Jyothi [1] states that efficient agricultural marketing in the economy generates gains in output and wages, raises agricultural producer prices, and reduces consumer prices. In addition, growth in the agriculture sector is two to four times more effective in raising incomes among the poorest compared to other sectors [2]. In 2014, Senyolo found that an estimated $80 \%$ from a study population was prepared to pay a premium for African leafy vegetables (ALVs). These findings bring to the fore the potential of enterprise diversification where local demand exists for specific products that do not compete with primary enterprises and in turn lead to profits. ALVs offer such potential and trade opportunities for farmers in rural areas. The opportunity is through the potential they possess to contribute to food security since a large percentage of the world's population depends on limited staple crops for nutrition and these include maize, wheat, and rice [3]. However, consumption of fruits and vegetables remains low globally $[4,5]$. This is in the mist of evidence that unhealthy diets, which involve a low intake of fruits and vegetables, are a major cause of diet related 
noncommunicable diseases in many countries, including in South Africa [6]. Thus, ALVs can play a major role in the diversification of the food basket. Recently, developing countries have embarked on optimising the consumption of their respective indigenous and traditional vegetable species, as well as destigmatize negative connotations association of these crops with poverty.

Several studies [7-10] highlighted some of the benefits of ALVs, and these include amongst others high micronutrient content, medicinal properties, and several agronomic advantages. The change in taste and preference of consumers is due to many reasons but what is outstanding is the healthy lifestyle that is adopted by the middle-high class. According to Muok [11] harvesting, utilization and marketing of indigenous products has been central to the livelihoods of most African communities. Irungu et al. [12] stated that ALVs also have a public value that includes maintenance of traditions and cultures, as well as contributing to sustainable development particularly in the conservation of biodiversity and additional ecosystem benefits. However, according to Lyatuu et al. [13], ALVs have long been regarded as minor crops and thus have attracted little marketing attention. A contributing factor to this limited marketing owes to the fact that most farmers produce ALVs for their own consumption with a small amount of the produce reaching the informal market where sales are through sales handled by women. Poor resources despite the crucial role they play in the poor rural economy mostly attribute ALV farmers. The advantage afforded to these ALV farmers stems from the limited resources required for production of these nutritious crops.

South African horticultural industry is growing in both quantities produced and prices received [14]. The industry growth is largely driven by expanding domestic demand, which is derived from the increasing number of middle-class consumers. This is also driven by global demand and potential for foreign earnings. The South African vegetable industry is undergoing a process of rapid transformation particularly in the value chain [15]. The expansion of different markets in the country and in the region is providing new channels for vegetable producers and promising an opportunity for smallholder farmers.

\section{Previous Studies on African Leafy Vegetables (ALVs)}

Many African communities had depended on ALVs for survival before introduction of exotic crops. Several studies [16-18] have shown that indigenous plants continue to play an essential role in the livelihoods of rural communities. Mbhenyane [19] indicated that the indigenous food has an economic value for the food security relief and development they provide in marginalised communities.

Underutilized food resources have a much higher nutrient content than globally known species or varieties commonly produced and consumed [20]. As cited by Omotayo et al. [21], Bvenura and Sivakumar [22] emphasize that the nutritional composition of indigenous and naturalized fruits and vegetables contribute positively to the human diet. However, some of the indigenous plants are only useful to fill small niche markets; others have the potential to become new products for consumers [23]. Market potential consists of customers interested of the market offer. Head and Mayer [24] indicate that market potential is a powerful driver of increases in income per capita.

With the rising population and urbanisation, demand for vegetable will continue to rise providing farmers and opportunity to explore that market. Shiundu and Oniang'o [25] in Kenya found that the market share of ALVs in comparison with other vegetable species has been on the upward trend, in the urban markets and increased consumption in rural areas too. Moreover, consumers were willing to pay an average premium of 79 percentage [26]. This tallied with the findings in [27] which indicated that demand and preference for African leafy vegetables were high among South African household.

The ALV marketing has some challenges, which include the lack of storage facilities, poor market structures, unreliable market arrangements, and transportation. It is also suggested that there are good opportunities to take greater advantage of ALVs as valuable local food resources [19]. It can also be noted that urban consumers are starting to be concerned about the safety and quality of their food.

\section{Materials and Methods}

A study was conducted in Capricorn district municipality located in the centre of the Limpopo Province, which is the economic development core of the province. This district comprises five local municipalities consisting 637 communities and a total population of 1409354 [28]. The municipalities of the district are Blouberg, Aganang, Molemole, Lepelle-Nkumpi, and Polokwane, and the district is predominantly rural dominated by the Northern Sotho ethnic group.

The study used cross-sectional data where primary data were collected through interviews using structured questionnaires. The selection of ALV farmers within the study area was done using the purposive sampling procedure. The list of indigenous leafy vegetables producers was obtained from Limpopo Department of Agriculture and Rural Development (LDARD). The study builds its analysis and conclusion on three crops, namely, amaranths (lerotho), spider flower (thepe), and cowpea (monawa). Elderly community members were regarded as primary sources of information in the study particularly women since they are known to have experience and knowledge on ALVs. The sample size was 60 households producing ALVs in rural areas of Capricorn district municipality.

The collected data were processed using the statistical software Stata. A stepwise discriminant analysis was performed to determine the variables that played an important role on the different market channel clusters these being local and neighbouring villages and hawkers in town. The market channel clusters were dependent variable, and explanatory variables were output, land cultivated with ALV, labour used, tractor costs, manure, age, farming experience, 
distance to local market, household size, gender, land ownership, off farm employment, vehicle ownership, and primary occupation. Microsoft office excel was used as a complementary tool to do a bubble map for market outlet concentration. Bubble map indicates the competitiveness and prospect for diversification of supply by farmers for ALVs. Bubble size was proportional to the share of each market for ALVs.

\section{Results and Discussion}

Two crops, amaranth and spider flower, which the study considered were not cultivated but harvested from the maize fields that used manure (kraal manure and chicken manure) for fertilisation. Only cowpea was cultivated, and most farmers consider it profitable because they benefited from sales of both the leaves and beans. All the crops that were investigated are rain-fed summer crops. Table 1 lists the ALVs considered for this study, common name, and the names the local used to refer to the crop.

Khoza et al. [29] highlighted that conditions of livelihood in the rural areas are reflected in the socioeconomic factors of households, which in turn influence the household's economic behaviour and affect market participation decisions. Table 2 indicates the socioeconomic characteristics of the 60 interviewed respondents consisting of $90 \%$ females and $10 \%$ male. In the African tradition context, women dominate the cultivation of ALVs as compared to men; thus, African leafy vegetables are regarded as "women crops." About $62 \%$ of sampled respondents were older than 60 years, and respondents younger than 60 were engaged in some other economic activities other than agriculture. It was very important to categorize the age in order to determine people of which age participate more in the cultivation of the study crops.

Farmers relied on pension as their main source of income, and it is used to support their grandchildren, as parents are either unemployed or located in other areas. These farmers had a lot of experience in producing indigenous leafy vegetables since they grew up farming these crops (ALVs). In terms of education level, $43 \%$ of the farmers had primary education and $37 \%$ had no formal education. Moreover, on average, households have six members affording the farmers a pool of additional labour. Approximately all ALV producers hold locally recognized customary land rights with a farmer, on average, having 1.29 hectares of land for production. However, the results indicate that the amount of land available to farmers varied from farmer to farmer.

4.1. Marketing of ALVs. Results indicated that farmers mostly sold between 50 and $60 \%$ of their produce, and the remaining produce is for consumption or sharing with the relatives, orphans, and poor community members who were not engaged in farming activities. All the ALV farmers participated only in the informal markets. Income from these sales helped to supplement the family income and put
TABle 1: African leafy vegetables (ALVs) considered in the study.

\begin{tabular}{lcc}
\hline Scientific name & Common name & Local name \\
\hline Vigna unguicalata & Cowpea & Monawa \\
Amaranthus cruentus & Amaranthus & Thepe \\
Cleome gynandra & Spider flower & Lerotho \\
\hline
\end{tabular}

them in a position to fulfil some of the household's basic needs.

It has been observed that farmers sold their products to three output markets, namely, locally and neighbouring villages, and in town (hawkers). Figure 1 outlines ALV market results from the study area. The $x$-axis represents markets, where 1 is the local market, 2 neighbouring villages, 3 supermarkets, and 4 town (hawkers) market. It was clear that local markets had a bigger market share of about $73 \%$ followed by town market with $20 \%$ and neighbouring village at $7 \%$. There was no evidence of ALVs reaching the supermarket. Most farmers sold their produce locally because of lack of market information and lack of resources to reach other markets. The reason neighbouring village markets absorb small percentage was because these neighbouring markets also supply ALVs. Similar observations were made by Berinyuy and Fontem [24], indicating that marketing channels for indigenous vegetables mainly included complex family networks.

The majority of local consumers buy from the farmer's house with few farmers selling door to door or at pension pay-out points. Distance to a neighbouring village on average was about $6 \mathrm{~km}$, and the largest selling points are pension pay-out points and shopping centres. The average distance to town output market was $35 \mathrm{~km}$, and farmers, who worked in town, especially as hawkers, mostly utilized this type of market. Respondents who were not working in town utilized the local markets in order to evade high transaction costs associated with marketing their products in town.

The lack of exploitation of the town marketing channels opened an opportunity for intermediaries who were hawking in town. This was supported by Manyelo et al. [30], stating that ALVs marketing and distribution is mainly through street vendors. However, there seems to be uncorroborated allegations that these intermediaries benefit significantly more as compared to farmers. Senyolo et al. [27] highlight that the relationships among the ALVs value chain actors were weak, with transactions based mostly on spot markets.

As found by most studies [24, 31, 32], even in the study area, females were the ones mainly undertaking ALVs marketing and other allied activities. Farmers were engaging limited marketing strategies, which were mostly traditional. They mostly advertised using the box note that hang on their household fence and relied mainly on the word of mouth which proves to be efficient.

Most farmers sell their produce both fresh and dry, with a small percentage that sells their product as either fresh or dry only. Prices charged ranged between R6.00 and R8.00 per bundle or pack. Dry products were priced significantly higher than the fresh products. This made an economic sense 
TABLE 2: Socioeconomic characteristics of the respondents.

\begin{tabular}{|c|c|c|c|c|c|}
\hline$N=60$ & & & & & \\
\hline Gender & & & & $\begin{array}{c}\text { Female } \\
90 \%\end{array}$ & $\begin{array}{c}\text { Male } \\
10 \%\end{array}$ \\
\hline Age* & & $\begin{array}{c}36-40 \\
2 \%\end{array}$ & $\begin{array}{c}41-50 \\
16 \%\end{array}$ & $\begin{array}{c}51-60 \\
20 \%\end{array}$ & $\begin{array}{l}>60 \\
62 \%\end{array}$ \\
\hline Marital status & & $\begin{array}{c}\text { Single } \\
17 \%\end{array}$ & $\begin{array}{c}\text { Married } \\
55 \%\end{array}$ & $\begin{array}{c}\text { Windowed } \\
28 \%\end{array}$ & $\begin{array}{c}\text { Divorced } \\
0 \%\end{array}$ \\
\hline Educational level & & $\begin{array}{c}\text { No FE } \\
37 \%\end{array}$ & $\begin{array}{c}\text { Primary } \\
43 \%\end{array}$ & $\begin{array}{c}\text { Secondary } \\
18 \%\end{array}$ & $\begin{array}{c}\text { Tertiary } \\
2 \%\end{array}$ \\
\hline Source of income & $\begin{array}{c}\text { Own salary } \\
8 \%\end{array}$ & $\begin{array}{c}\text { Farming } \\
3 \%\end{array}$ & $\begin{array}{c}\text { Pension } \\
68 \%\end{array}$ & $\begin{array}{c}\text { Social grant } \\
5 \%\end{array}$ & $\begin{array}{c}\text { Hawking } \\
16 \%\end{array}$ \\
\hline Number of dependants $* * *$ & & $\begin{array}{c}1 \\
8 \%\end{array}$ & $\begin{array}{l}2-6 \\
82 \%\end{array}$ & $\begin{array}{l}7-11 \\
10 \%\end{array}$ & $\begin{array}{c}12-16 \\
0 \%\end{array}$ \\
\hline
\end{tabular}

* Recorded in years; $* * *$ counting of individuals in a household included infants to the elderly. FE, formal education.

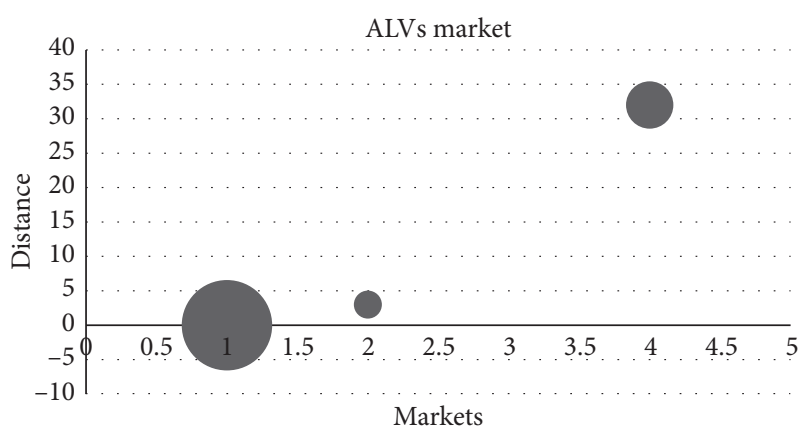

FIGURE 1: Bubble map representing the market, market share, and distance to market. 1 represents the local Capricorn district municipality market, 2 represents the neighbouring villages within the Capricorn district municipality, 3 represents the supermarkets within the Capricorn district municipality, and 4 represents the town hawkers market within the Capricorn district municipality. The distance to different output markets varied.

because of the value added to the product by processing and packaging. A large percentage of farmers set their price based on the market price with few setting their price as dictated by buyers. Bulk buyers dictated prices, which led to low prices. However, farmers did not have a problem as they manage to sell larger quantities.

4.2. Drivers of Market Choice. A stepwise discriminant analysis was used to analyse factor that affects the drivers of the market choice for ALVs. Analysis of the factors affecting market participation decisions of smallholder farmers helps to design appropriate interventions for their sustainable economic development. Elements such as education, farming experience, skills, age, rural or urban location, language, and physical well-being also influence output market access.

The study's results indicate that socioeconomic factors play a major role on the choice of output market for ALVs. These results in addition to other studies showed that the major determining factors influencing farmer's participation in the market are age, marital status, source of labour, farming experience, and farm size [33]. The probability of participating in output markets depends on household size, distance to the nearest marketing channel, price of the commodity, and gender of the farmer [34]. When a stepwise discriminant analysis was performed to find the drivers that played the most important role in distinguishing the difference between the three market channels, only four factors were identified and these were gender, land ownership, farming experience, and age of the farmer. Older farmers with more than 15 years of farming experience used market channel 1 while farmers who had less than 15 years' experience used market channel 2 and channel 4 (centroid F1 of Figure 2). The possible explanation could be that older people have more contacts locally as they have been farming for a long time. The other possible explanation could be that younger farmers are more progressive and more receptive to new ideas and have better understanding of the benefits of accessing different markets where the supply is not high [35]. Female farmers and farmers who owned land used market channel 1, channel 2, and channel 4 (Figure 2). Male farmers and farmers who leased land used market channel 2 only (centroid F2 of Figure 2). Females are dominating the marketing of ALVs as it evidence with their presence in every channel.

4.3. Marketing Channels of $A L V$. The marketing channels in Figure 2 shows how ALVs currently flow via several alternative supply chain paths from farm to various output markets in the study area. The study reveals that farmers were utilizing two distribution channels to supply their product to customers. In the first channel, farmers supplied their produce directly to consumers. This distributional channel is mostly to rural consumers but with an exception of small percentage to urban consumers. On this route, farmers supplied both fresh and dried produce. The advantages of this marketing channel include the absence of marketing costs involved, not sophisticated, and easy to access.

The second channel entails where farmers supplied hawkers with both fresh and dried products. Intermediaries in this case, the hawkers, added value to the fresh product by drying and packaging. With these routes, hawkers sell to the final consumer. Intermediaries tend to get more money than 


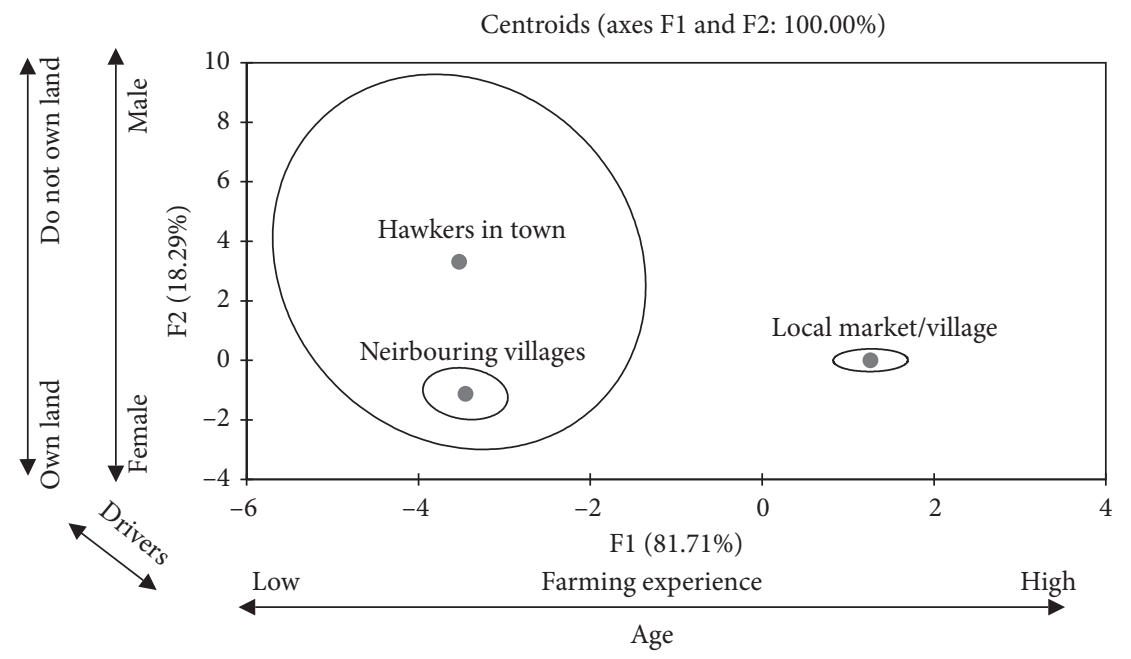

FIgUre 2: A schematic representation of the African leafy vegetables (ALVs) market drivers.

farmers themselves because of high prices they charge as they sell in areas where ALVs were scarce. Based on the study results in Figure 3, it is visible that farmers were not utilizing all the available distributional channels.

4.4. Consumer Perception of ALVs. Throughout the world, major shifts in dietary patterns are occurring, even in the consumption of basic staples towards more diversified diets. Accompanying these changes in food consumption at a global and regional level has been considerable health consequences (Kearney, 2010). Shiundu and Oniang'o (2007) highlighted that ALVs were fast becoming the vegetable of choice, especially in the previously, nonconsuming segments of the society including the upper- and middleclass households and generally among the elite in Kenya.

Results show that socioeconomic factors of the household influenced the consumption and perception towards ALVs. Consumers interviewed were both from rural and urban areas of the Capricorn district. Ninety-two percent (92\%) of respondents (consumers) were females; this was because they were the ones who mostly cook in the household. ALVs played a vital role in the diet of both urban and rural consumers. Households preferred different types of ALVs, but most people consumed all ALVs considered in the study; these products were consumed in their fresh and dried states. The main source of income for rural consumers was found to be a social grant and in the urban areas was found to be salary. Faber et al. [36] found that communities in Limpopo preferred to dry ALV leaves for consumption in winter. Other consumers in their study boiled the leaves in salted water followed by steaming or frying for consumption.

Consumers source their products from farmers and hawkers. Ninety-five percent of respondents indicated that they would be very interested in buying the products from retailers, the reason being that retailers are hygienic and easily accessible, and they will be assured of constant supply. Attitude of respondents who were consumers of ALV was mostly negative since they value ALVs but seemed to be shy

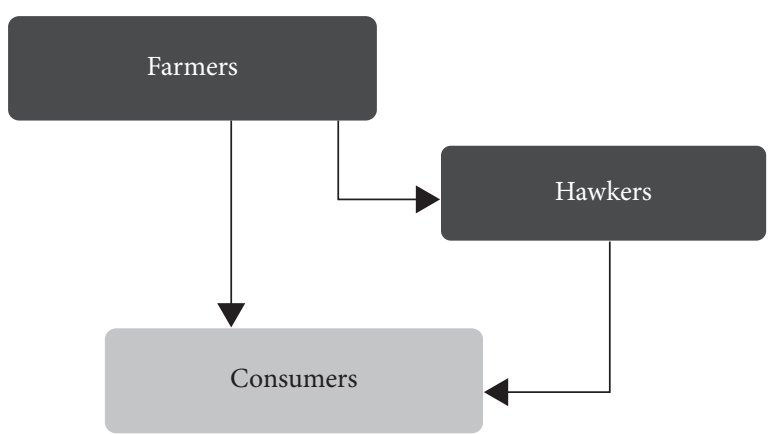

Figure 3: A chain diagram depicting the value chain of African leafy vegetables (ALVs).

about these crops. A large number about $80 \%$ of respondents do not serve ALVs to visitors, and they only serve when visitor asked for it especially the one from urban areas. ALVs taste is preferred because of its uniqueness. According to Mavengahama [8], closer market distance increased acceptance of leafy ALVs, and other studies named the top four most popular ALVs as amaranth, spider plant, wild watermelon, and blackjack, all of which were harvested by rural households from the wild and obtained from informal markets by urban dwellers [36]. These studies further explained that some consumers considered ALVs as vegetables for the poor, and this perception has decreased the acceptance of these vegetables by high-value chain markets. Improved knowledge of ALVs among urban male and younger rural household decision makers could increase acceptance of leafy ALVs.

4.5. Potential Market. In South Africa, there is an increasing change in consumer's expectations and demands for food where consumers are starting to prefer quality and easy to prepare food. This phenomenon is occurring concurrently with studies highlighting deficiency of micronutrients and obesity especially among children and women [37]. According to the Department of Health (DoH) of South 
Africa, vitamin A deficiency is a major contributor to underfive mortality and has been shown to cause visual impairment and increase the risk of measles and diarrhoea. For the need to address this deficiency and its impact, ALV farmers are presented with an opportunity to participate in the mainstream as these crops are highly nutritious.

Urban and township consumers present a great potential as these regions are populated by middle class, which mostly move with the trends, and they are becoming health conscious. The emergence and growth of this class increases the potential of the absorption of ALVs as a significant number of this class grew up consuming these crops. Considering demand drivers, ALVs stand a greater chance to be absorbed by the black middle class. The Global Wealth Report 2015, published by Credit Suisse, found that middle-class South Africans accounted for $13.7 \%$ of the country's adult population. A study conducted by the Unilever Institute at the University of Cape Town (UCT) in 2016 revealed an increasing trend of the black middle class between 2004 and 2015 from 1.74 million to 5.61 million. This is a significant population, which can absorb large quantities of ALVs. This population has some level of disposal income, which they are willing to spend. The results depict growth of the black middle class in relation to the white, coloured, and Indians of South Africa's population.

Upon comparison with commonly consumed commercial vegetables such as white cabbage, tomato, and onions, many ALVs are relatively richer in vitamins, minerals, dietary fiber, and protein [38]. Kamga et al. [39] further stated that an increased production and consumption of these nutrient-rich ALVs would help reduce the nutritionrelated disorders in Africa. Some of these ALVs have also been found to contain medicinal properties, which can treat a wide range of diseases $[40,41]$. Periurban and urban areas have a significant number of supermarkets as well as fruit and vegetable outlets. This availability has the potential to serve as access points for potential customers to access the crops since the availability serves as a readily available market. In addition, the potential targeted market does not have time to farm in their areas since the majority do not own land for agricultural production. However, farmers will have to package the crop to make it attractive to the targeted market since the targeted market is sophisticated and trendy. It is worth noting that there would be a need for an intense awareness programme to promote these crops. The consumers will need education on the health benefits of ALVs, thus changing the consumer's perception of ALVs. These crops can also be promoted in hospitals, schools, and correctional facilities considering their health and medicinal properties.

\section{Conclusion}

ALVs have the potential to be introduced as cash crops in periurban and urban systems in South Africa, as vegetables for daily consumption and to assist food security strategies. There is a potential market that exists among the middle class and supermarkets as potential channel for ALVs. The financial and health benefits of ALVs are immense, but a sustainable success will need an intense marketing and awareness of these benefits. Consumers need to be informed of all the benefits associated with these crops particularly the nutritional value. Awareness campaigns will thus play a vital role in this instance, and these should target alteration of consumers' perception of ALVs with the intent to ease the introduction of these crops to their daily consumption. The success of such campaigns will in turn create a demand of these crops facilitating their entry into the mainstream food system. The demand for ALVs will subsequently lead to introduction of an essential income stream for rural farmers as these crops have a comparative agronomic advantage over other commercially consumed crops. This translates to rural farmers avoiding competition with well-established farmers with immense surplus of input bargaining powers since ALVs require less input. It is therefore suggested that the Department of Agriculture in Limpopo Province creates a conducive environment through which ALVs farmers can access local markets for the benefit of these farmers with a causal sequence to benefit Limpopo Province consumers concerning food security.

\section{Data Availability}

The data used to support the findings of this study are available from the corresponding author upon request.

\section{Conflicts of Interest}

The authors declare that they have no conflicts of interest.

\section{References}

[1] K. C. Jyothi, "Agricultural marketing and sustainable development," IOSR Journal of Economics and Finance, vol. 4, no. 2, pp. 1-8, 2014.

[2] World Bank, Agriculture and Food, World Bank, USA Washington, DC, 2020, https://www.worldbank.org/en/topic/ agriculture/overview $\% 231$.

[3] J. M. Awika, V. Piironen, and S. Bean, Advances in Cereal Science: Implications to Food Processing and Health Promotion ACS Symposium Series, American Chemical Society, Washington, DC, USA, 2011.

[4] D. Mason-D’Croz, J. R. Bogard, T. B. Sulser et al., "Gaps between fruit and vegetable production, demand, and recommended consumption at global and national levels: an integrated modelling study," The Lancet Planetary Health, vol. 3, no. 7, pp. e318-e329, 2019.

[5] K. R. Siegel, "Insufficient consumption of fruits and vegetables among individuals 15 Years and older in 28 low- and middleincome countries: what can Be done?" The Journal of $\mathrm{Nu}$ trition, vol. 149, no. 7, pp. 1105-1106, 2019.

[6] S. Godrich, K. Kent, S. Murray et al., "Australian consumer perceptions of regionally grown fruits and vegetables: importance, enablers, and barriers," International Journal Environmental Research and Public Health, vol. 17, no. 63, 2020.

[7] M. O. Abukutsa-Onyango, "Unexploited potential of indigenous African vegetables in Western Kenya," Maseno Journal of Education Arts and Science, vol. 4, no. 1, pp. 1035-122, 2013.

[8] S. Mavengahama, The contribution of indigenous vegetables to food security and nutrition within selected sites in south africa, 
Ph.D. Thesis, Stellenbosch University, Cape Town, South Africa, 2013.

[9] C. Njume, N. I. Goduka, and G. George, "Indigenous leafy vegetables (imifino, morogo, muhuro) in South Africa: a rich and unexplored source of nutrients and antioxidants," African Journal of Biotechnology, vol. 13, no. 19, pp. 1933-1942, 2014.

[10] W. Van Averbeke, M. P. Chabalala, A. O. M. Okorogbona, T. D. Rumania, J. O. Azeez, and M. M. Slabbert, "Plant nutrient requirements of African leafy vegetables," in $\mathrm{Nu}$ tritional Value and Water Use of African Leafy Vegetables for Improved Livelihoods; WRC TT535/12, Water Research Commission, Pretoria, South Africa, 2012.

[11] B. O. Muok, "Potentials and utilization of indigenous fruit trees for food and nutrition security in east Africa," Global Advanced Research Journal of Agricultural Science, vol. 8, no. 2, 2019.

[12] C. Irungu, J. Mburu, P. Maundu, M. Grum, and I. HoescleZeledon, Analysis of Markets for African Leafy Vegetables within Nairobi and its Environs and Implications for On-Farm Conservation of Biodiversity, A consultancy report for Global Facilitation Unit for Underutilised Species, Rome, Italy, UK, 2007.

[13] E. Lyatuu, L. Lebotse, G. Msuta, and M. Marope, "Marketing of indigenous leafy vegetables (ALVs), and how small-scale farmer income can be improved in SADC region (Tanzania, Zambia and Botswana)," regional workshop report, Implementation and Coordination of Agricultural Research and Training in the SADC Region, Gaborone, Botswana, 2009.

[14] 2016 http://www.daff.gov.za/statisticsDepartment of Agriculture, Forestry and Fisheries (DAFF).

[15] S. Barrientos and M. Visser, South African Horticulture: Opportunities and Challenges for Economic and Social Upgrading in Value Chains. Capturing the Gains Working Paper 2012/12, University of Manchester, Oxford, Manchester, UK, 2012, https:/globalvaluechains.org/sites/ globalvaluechains.org/files/publications/ctg-wp-2012-12.pdf.

[16] T. Mabhaudhi, T. P. Chibarabada, V. G. P. Chimonyo et al., "Mainstreaming underutilized indigenous and traditional crops into food systems: a south African perspective," Sustainability, vol. 11, p. 172, 2019.

[17] K. Magwede, B.-E. Van Wyk, and A. E. Van Wyk, "An inventory of Vhavenda useful plants," South African Journal of Botany, vol. 122, pp. 57-89, 2019.

[18] S. P. Mashile, M. P. Tshisikhawe, and N. A. Masevhe, "Indigenous fruit plants species of the mapulana of ehlanzeni district in mpumalanga province, south africa," South African Journal of Botany, vol. 122, pp. 180-183, 2019.

[19] X. G. Mbhenyane, "Indigenous foods and their contribution to nutrient requirements," South African Journal of Clinical Nutrition, vol. 30, pp. 5-7, 2017.

[20] P. Durst and N. Bayasgalanbat, Promotion of Underutilized Indigenous Food Resources for Food Security and Nutrition in Asia and the Pacific, Food and Agriculture Organization of the United Nations Regional Office for Asia and the Pacific Bangkok, Bangkok, Thailand, 2014, http://www.fao.org/3/ai3685e.pdf.

[21] A. O. Omotayo, P. T. Ndhlovu, S. C. Tshwene, and A. O. Aremu, "Utilization pattern of indigenous and naturalized plants among some selected rural households of north west province, South Africa," Plants, vol. 9, no. 8, p. 953, 2020.

[22] C. Bvenura and D. Sivakumar, "The role of wild fruits and vegetables in delivering a balanced and healthy diet," Food Research International, vol. 99, pp. 15-30, 2017.
[23] J. Gockowski, J. Mbazo'o, G. Mbah, and T. Fouda Moulende, "African traditional leafy vegetables and the urban and periurban poor," Food Policy, vol. 28, no. 3, pp. 221-235, 2003.

[24] J. E. Berinyuy and D. A. Fontem, "Evaluating post harvest opportunities and constraints to utilization and marketing of African leafy vegetables in Cameroon," African Journal of Food, Agriculture, Nutrition and Development, vol. 11, pp. 4646-4663, 2011.

[25] R. K. Oniang'o, M. K. Shiundu, and P. T. Maundu, "Johns African Leafy Vegetables: Efforts to Change a Traditionally Subsistence Crop into a Major Driver in Poverty Alleviation and Improvement of Health in sub-Saharan Africa," International Consultation on the Value of Bio-diversity in Achieving the UN Millennium Development Goal of Freedom from Hunger and Poverty, Chennai, India, 2007.

[26] P. K. Chelang'a, G. A. Obare, and S. C. Kimenju, "Analysis of urban consumers' willingness to pay a premium for African Leafy Vegetables (ALVs) in Kenya: a case of Eldoret Town," Food Security, vol. 5, pp. 591-595, 2013.

[27] G. M. Senyolo, E. Wale, and G. F. Ortmann, "Consumers' willingness-to-pay for underutilized vegetable crops: the case of african leafy vegetables in South Africa," Journal of Human Ecology, vol. 47, no. 3, pp. 219-227, 2014.

[28] University Of South Africa (UNISA), "Population Estimates for South Africa by district municipality and province, 2010," Extract From BMR Research Report 402, University Of South Africa (UNISA), Pretoria, South Africa, 2011.

[29] T. M. Khoza, G. M. Senyolo, V. M. Mmbengwa, and P. Soundy, "Socio-economic factors influencing smallholder farmers' decision to participate in agro-processing industry in Gauteng province, South Africa," Cogent Social Sciences, vol. 5, no. 1, p. 1664193, 2019.

[30] K. W. Manyelo, W. van Averbeke, and P. Hebinck, "Smallholder irrigators and fresh produce street traders in Thohoyandou, Limpopo province, South Africa," in Rural Development and the Construction of New Markets, pp. 131-148, Routledge, London, UK, 2015.

[31] E. O. Gogo, A. Opiyo, C. Ulrichs, and S. Huyskens-Keil, "Loss of African indigenous leafy vegetables along the supply chain," International Journal of Vegetable Science, vol. 24, no. 4, pp. 361-382, 2018.

[32] I. A. Olabode, O. A. Adetula, G. S. Akinwumi, and A. A. Layade, "Marketing analysis of indigenous leafy vegetables in the tropics," International Journal of Vegetable Science, vol. 23, no. 3, pp. 226-232, 2017.

[33] O. A. Egbetokun and B. T. Omonona, "Determinants of farmers' participation in food market in ogun state," Global Journal of Science Frontier Research Agriculture and Veterinary Sciences, vol. 12, no. 9, pp. 24-30, 2012.

[34] O. Onoja, B. B. Usoroh, D. T. Adieme, and N. J. Deedam, "Determinants of market participation in Nigerian small scale fishery sector: evidence from Niger delta region," Journal of Sustainable Development, vol. 9, no. 1, pp. 69-84, 2012.

[35] M. Mathenge, F. Place, J. Olwande, and D. Mithoefer, "Participation in agricultural markets among the poor and marginalized: analysis of factors influencing participation and impacts on income and poverty in Kenya," Tegemeo Institude of Agriculturasl Policy and Development and World Agroforestry Centre, Nairobi, Kenya, 2010, http://www.tegemeo.org/ documents/other/Report-on-Market-Participationamongthe-Marginalized-groups-in-Kenya-Final-Report-Kenya-v3. pdf.

[36] M. Faber, A. Oelofse, P. Van Jaarsveld, F. Wenhold, and W. Jansen Van Rensburg, "African leafy vegetables consumed 
by households in the Limpopo and KwaZulu-Natal provinces in South Africa," South African Journal of Clinical Nutrition, vol. 23, no. 1, pp. 30-38, 2010.

[37] O. Shisana, D. Labadarios, T. Rehle et al., South African National Health and Nutrition Examination Survey (SANHANES-Cape Town, HSRC Press, Cape Town, Africa, 2013.

[38] R. Y. Yang and G. B. Keding, "Nutritional contributions of important african indigenous vegetables," African Indigenous Vegetables in Urban Agriculture, pp. 105-143, Earthscan, London, UK, 2009.

[39] R. T. Kamga, C. Kouamé, A. R. Atangana, T. Chagomoka, and R. Ndango, "Nutritional evaluation of five African indigenous vegetables," Journal of Horticultural Research, vol. 21, no. 1, pp. 99-106, 2013.

[40] O. C. Aworh, From Lesser Known to Super Vegetables: The Growing Profile of African Traditional Leafy Vegetables in Promoting Food Security and Wellness, Wiley Online Library, New York, NY, USA, 2018, https://onlinelibrary.wiley.com/ doi/pdf/10.1002/jsfa.8902.

[41] E. K. Mibei, N. K. O. Ojijo, S. M. Karanja, and J. K. Kinyua, "Phytochemical and anti- oxidant analysis of methanolic extracts of four African indigenous leafy vegetables," Annals Food Science and Technology, vol. 13, no. 1, pp. 37-42, 2012. 